\title{
Determinants of Micro and Small Enterprises Growth in Selected Towns of West Shoa Zone, Oromia Regional State, Ethiopia
}

\author{
Negash Geleta \\ Department of Management \\ College of Business and Economics \\ Ambo University, Ethiopia \\ E-mail:kenu2002@gmail.com \\ Sileshi Talegeta \\ Department of Management \\ College of Business and Economics \\ Ambo University, Ethiopia \\ E-mail:getasileshi@gmail.com
}

\begin{abstract}
MSEs have an important contribution to economic growth and employment creation in Ethiopia. However, due to different bottlenecks that hinder the growth, MSEs found in these three towns were not grown as it was expected. Therefore, this study aimed at identifying the major determinants of MSEs growth in West Shoa Zone, Oromia region, Ethiopia. In the study, both qualitative and quantitative research methods were used. Primary data was obtained using questionnaires. Stratified sampling was used to select proportional number of samples from the study area. The study used Chi-square and logistic regression to measure the association and determine growth probability of MSEs, respectively. The result of the study revealed, Entrepreneurial competency, managerial skills, market access, innovation, high initial investment size, access to finance and manufacturing sector variables were identified as a major determinant of growth of the MSEs in the study area. MSEs Owner/manager characteristics such as gender and age were found not to have an influence on the growth of the enterprises as the descriptive result showed. The probability of growth of MSEs were positively influenced by entrepreneurship competency, management skill, market access, initial investment size, and sector in manufacturing; however, getting access to finance and engaging in innovation activity have negative impact on the growth probability of MSEs based on the binary logit model result. The variables included in the model explain about $73.38 \%$ of the influences on the MSEs Growth so as, the model is fit. The study recommends that proper understanding of these factors constitutes an essential starting point and important for the Owner/manager of MSEs, government and non-governmental organizations to formulate policies and strategies in order to reduce unemployment, poverty and income inequality thereby promote MSEs and their growth in the country and particularly in West Shoa Zone.
\end{abstract}

Keywords: Determinants of growth; MSEs; Logistic regression

\section{Introduction}

Micro and Small Enterprises (MSEs) are widely recognized as a major source of employment and income in developing countries (Mano et al., 20II). Worldwide MSEs have been recognized as engines of growth, development and usually as the backbone of national economies. MSEs have increased in importance recently (McCartan and Carson 2003). Many countries have put considerable efforts to support them so as to create and tap their employment opportunities, income and productive capacity.

The sector has employment potential at low capital cost and playing as a major role in the country. The sector is also known in bringing economic transition by effectively using the skill and the talent of people without having high-level training, much capital and sophisticated technology. As a result, the MSEs sector is described as the natural home of entrepreneurship since it provides an ideal environment that enable entrepreneurs to exercise their talents to fill and attain their goals. This makes MSEs a major area of concern for government and non-government organizations with an objective of unemployment reduction, income generation and equitable income distribution, import substitution, innovation, and poverty alleviation.

Micro and small enterprises are known by their greater utilization of local raw materials, employment generation, take part in rural and urban development, development of entrepreneurship, mobilization of local savings, linkages with bigger industries, provision of regional balance by spreading investments more evenly, provision of avenue for self-employment and provision of opportunity for training managers and semi-skilled workers (Maad, 2008). 
MSEs are found in every economy, either in developing economy or developed economy. In either case, they play significant role in the growth and sustainability of growth of countries. The roles of MSEs in the creation of productive employment are concerned with its position in the centre of the range of sizes and resource intensities in a rising economy. Accordingly, developing economies have started to focus on the crucial role that MSEs can play in development (Maad, 2008). In most countries, there are small number of large enterprises, larger number of medium enterprises and very large number of micro enterprises (Tarmidi, 2005). In Ethiopia, MSEs are the second largest employment generating sector next to agriculture. A National survey conducted by Central Statistics Agency of Ethiopia (CSAE) in 2007 indicates that more than I.3 million people in the country are engaged in MSEs Sector.

The government of Ethiopia is focusing on the MSEs basically because of their great contribution in reducing unemployment. The focus stems from the increasing of unemployment problem in Ethiopia, and MSEs have significant role in poverty alleviation and job creation (Solomon, 2005). However, there are many problems that affect the growth and expansion of MSEs. These are lack of initial capital, lack of business development services, lack of access to market, delay of credits and others. The purpose of the study was therefore to examine factors determining the growth of micro and small enterprise at West Shoa Zone selected Woredas.

The small business sector is recognized as an integral component of economic development and a crucial element in the effort to lift countries out of poverty (Wolfenson, 200I). Small-Scale businesses are the driving force for economic growth, job creation, and poverty reduction in developing countries. They have been the means through which accelerated economic growth and rapid industrialization have been achieved (Harris et al, 2006; Sauser, 2005). Furthermore, small scale business has been recognized as a feeder service to large- scale industries (Fabayo, 2009). While the contributions of small businesses to development are generally acknowledged, entrepreneurs in this sector face many obstacles that limit their long term survival and development. Scholars have indicated that starting a business is a risky venture and warned that the chances of small-business owners making it past the five-year mark are very slim (ILO, 2005). Some researches in small-business development have also shown that the rate of failure of small scale businesses in developing countries is higher than in the developed world (Marlow, 2009). Margi and Philip (2005) argued that growth is determined by a combination of the entrepreneur, the strategy and the firm organization. They also describe key influences on MSEs Growth as internal factors (entrepreneurial influences, managerial skill, marketing and innovation) and external factors (financial support laws and regulations, access to market and competition globalization).

The survey by the Central Statistical Authority of Ethiopia (ECSA, 2004), indicated that the increased role and contribution that the MSEs sector could have provided to the national economy is largely constrained by the various policy, structural and institutional related problems and bottlenecks. Lack of supply of raw materials and working premises were reported to be the major bottlenecks facing small scale manufacturing industries, while lack of sufficient capital and working premises were the leading problems of the informal sector operators to start their businesses.

According to the data obtained from the selected towns, MSEs are no performing well on the basis of the plans. Particularly, the growth plan from Micro to Small for Bako Tibe was 47 in 2006 E.C but the performance was only I6. Similarly, the plan of Gedo was 40 in the year of 2006, but the performance was only I0 enterprises (MSEs west Shoa zone office Report, 2006 E.C).

Different empirical studies have been conducted in Ethiopia and in other countries related to MSEs growth. Among the studies, Habtamu et al., (2013) examined MSEs growth in Mekelle city in terms of initial investment, location, gender and sector where as Mulu (2007) incorporated in his study the size, age, sector, and gender as determinant factors for MSEs growth in Ethiopia. His study showed that there was strong evidence that innovators grow faster than non-innovators. In addition, Ruhiu et al., (2014) conducted the study on the effects of managerial skills on the growth of incubated MSEs in Kenya. Likewise, Ongoro et.al (2013) found that managerial skills have a strong, positive and significant influence on the growth of MSEs. Moreover, Kamau and Ngugi (20I4) considered in his study that access to markets, social network, entrepreneur skills and financial access as factors influencing MSEs growth.

Therefore, this study investigated factors determining the growth of MSEs by incorporating entrepreneurial skills, managerial skills, innovation, and access to finance, access to markets, initial investment and sector variables in West Shoa Zone selected Woredas. To this effect, the study address the following research questions, what is the status of MSEs growth in West Shoa Zone, and which factors were more critically determine the growth of MSEs.

The study examined the factors determining the growth of Micro and Small Enterprise in West Shoa Zone in case of Ambo, Bako and Gedo Towns. The specific objectives were:

- To assess the status of MSEs growth in West Shoa Zone selected towns

- To describe factors that influence MSEs growth in West Shoa Zone selected towns

- To examine the determinant factors of MSEs growth in West Shoa Zone selected towns 


\section{Hypothesis of the Study}

The hypotheses of the study were developed from previous empirical studies:

Hr: Relatively the better entrepreneurship competency and managerial skills of the MSEs, the higher the chance of the growth.

$\mathrm{H}_{2}$ : MSEs that are engaged in innovation activity likely grow faster than the non-innovators

$\mathrm{H}_{3}$ : MSEs that have better market access, the higher probability of growth as compared to those MSEs that have poor market access.

$\mathrm{H}_{4}$ : Relatively the higher the initial investment sizes of the MSEs, the higher the chance of growth

Hs: MSEs that have better access to finance, the higher probability of growth as compared to those enterprises' that have poor access to finance.

H6: MSEs that are engaged in manufacturing sectors have higher chance of growth than those MSEs that are engaged in other sectors.

3. Conceptual Framework of the study

There is hardly any unique, universally accepted definition of MSEs. Egbuogu (2003) noted that definitions of MSEs vary both between countries and between continents. Therefore, the Ethiopian government defines as MSEs (MSEs Survey, 20I3). Micro Enterprise- when the numbers of its employees (including the owner or family) are not greater than 5 and total asset is $\leq$ I00,000 ETB for industrial sector and $\leq 50,000$ ETB for service sector. Small Enterprise is an enterprise with 6-30 employees and total asset of 100,00I-I,500,000 ETB for industrial sector and 50,000I-500,000 ETB for service sector. In this study, the firm growth is measured using change in employment size since startup (Storey, 1994).

The independent variables that are critically examined and identified from empirical studies for this study as MSEs growth determining factors are Entrepreneurial competency, Managerial skills, Access to markets, Initial investment size, Sectors, Access to finance, and Engagement of MSEs in innovation activities. Thus, the above hypothesis is formulated in this manner from different studies.

Entrepreneurship competency is increasingly recognized as an important driver of economic growth and it is widely accepted as a key strategy for success of MSEs and has a significant and positive effect on growth of the MSEs as revealed by the study of Kamau and Ngugi (2014) in Nigeria. Managerial skills play a great role for the growth of MSEs as previous study of Ongoro et al., (2013) depicted which has a positive and significant influence on the growth of MSEs.

Limited access to markets forces leads to MSEs to operate in the low-income market segments, which limits sales/profits as they compete for the same customers (Sengendo et al., 200I). This discourages MSEs' future growth potential. As the study of Ishengoma and Kappel, (20II) indicated access to markets has a significant and positive effect on the MSEs Growth. MSEs that are started operation with higher initial investment are more likely to grow than relatively smaller initial investment (Barney, 199I; Carroll, I993). Moreover, the study of Habtamu et al., (2013) indicated that the initial investment has a significant contribution for the MSEs' growth.

As the previous studies revealed access to finance is affect the growth of MESs' this also shown in Ethiopia by the study of Mulu G.(2009) that access to finance has positive effect on MSEs' growth. MSEs operating in manufacturing and service sector grow faster than those in trade/service as the study of Habtamu et al., (2013) and Gebreyesus, (2007). Furthermore, Mulu's (2009) study in Ethiopia revealed that sector selection significantly affects growth of MSEs.

The previous study by Mulu (2009) MSEs revealed that Innovators grow faster than non-innovators. But MSEs in unstable condition cannot increase the chances of probability of growth in being more innovative than wasting a large amount of resources. But this study contradicts the previous study of Mulu. However in long run, engaging in innovation activity can contribute a lot for the growth of MSEs.

Figure 2.I: Conceptual relationship between determinate factors and growth of MSEs

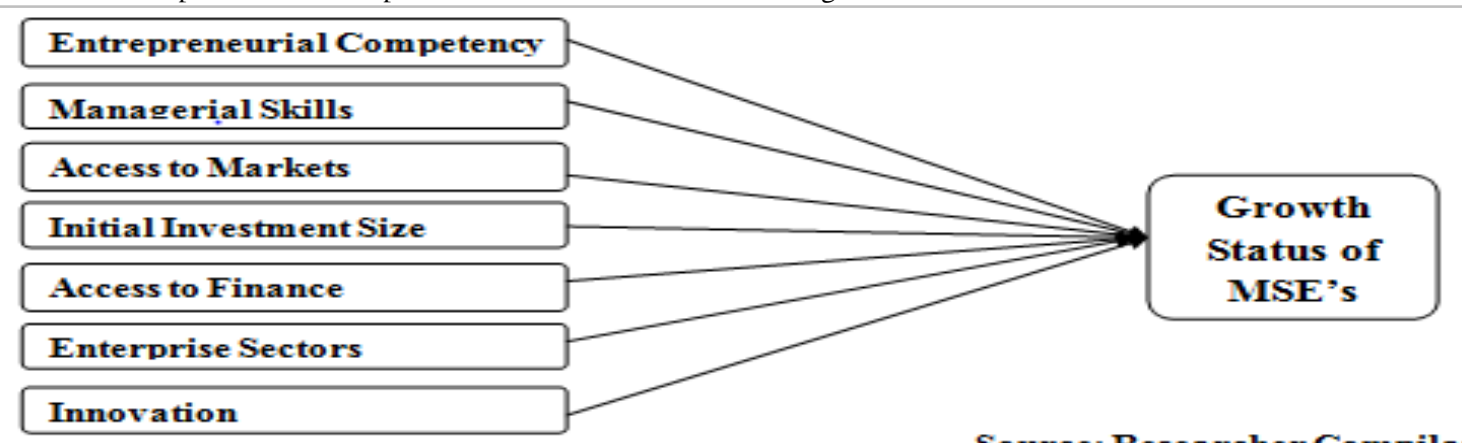

Source: Researcher Compilation

${ }^{1} 1 \$ \approx 22.60 \mathrm{ETB}$ 


\section{Materials and Methods}

The study was conducted in Ethiopia, Oromia regional state, West Shoa Zone, in selected three Towns i.e Ambo, Gedo and Bako. Designs of the study were both descriptive and explanatory. Data was obtained from primary and secondary sources. Primary data directly collected from the respondents (the manager/owner of the MSEs) and secondary data were collected from books and journals.

\section{Sample size and Sampling Techniques}

The total populations were 1266 from the three selected towns of MSEs. From these populations, 304 sample sizes were selected using Yamane (1996) formula but out of the collected questionnaire only 243 samples were appropriate for data analysis which means $80 \%$ response rate is obtained. From the four sectors of MSEs' included in the study manufacturing, construction, trade and service, accounts 8I, 20, 77 and 65, respectively. After sample size determined simple random sampling technique were used to select the target from each sector.

\section{Method of Data Analysis}

Data were analyzed using descriptive and inferential statistics. Descriptive statistics were used to analyze MSEs owner/manager demographic characteristics. SPSS and STATA software employed to process the data using Chi-square and binary logistic regression which measure the association and growth probability of MSEs.

The growth of MSEs is subject to different set of interrelated factors (Baldwin, 1995) in order to investigate the factors that determine the growth status of MSEs, using binary logistic regression model due to the nature of dependent variable, if the dependent variable is categorical variable with only two categories (growing \& non-growing/survival valued as $\mathrm{I} \& 0$ respectively), binary logistic (logit) regression is appropriate. The logitis preferred than probit model because of its simplicity and more meaningful interpretation of odds ratio (Gujarati, 2004). The study, MSEs was assumed to be either growing or survival (not growing) which is more appropriate for this model since binary choice logistic regression model assumes dichotomous dependent variable which takes either $\mathrm{I}$ or 0 value depending on $\mathrm{Y}^{*}$ is used. This is specified as:

\section{$\mathbf{Y}=\frac{1 \text { if } \mathbf{Y}^{*}>0}{\mathbf{0} \text { if } \mathbf{Y}^{*} \leq \mathbf{0}}$}

In this study MSEs Growth rate was computed by taking the natural logarithm of change in employment size over the life of the firm following Evans (1987) model.

MSE_GR $=\frac{\left(\ln S_{\mathbf{t}^{\prime}}-\ln \mathbf{S}_{\mathbf{t}}\right)}{\mathbf{E a}}$

Taking the calculated growth rate, the MSEs are classified in to two broad categories i.e., growing (if growth rate $>0$ ) and not growing following Cheng (2006) growth classification.

\section{The employed model was:}

\section{$S E_{G R}=\alpha+\beta_{1} E n t r \_C o m p+\beta_{2} M g t \_S k i l l+\beta_{3} M k t \_A c c e s s+\beta_{4} I n n o v+\beta_{5} I n i_{-} I n v+\beta_{6} F i n \_A c c e s S$ $+\beta_{7} \operatorname{Sec}+\varepsilon_{i}$}

Where $\boldsymbol{\alpha}$ the intercept, $B_{\mathrm{I}-7}$ is the coefficient to be estimated, Entr_Comp is the entrepreneurial skill of enterprise owner/manager, Mgt_Skill is managerial skill, Ini_Inv is initial investment size, Innov is the innovation of the enterprise, Mkt_Access is the enterprise operation location, Fin_Access is access to finance, Sec is the enterprise sector of operation and $\boldsymbol{\varepsilon}_{\mathrm{i}}$ is the error term that has a logistic distribution with mean 0 and variance $I$.

Table 3.I: Variable Codes, definition and expected sign of the explanatory variables

\begin{tabular}{|c|c|c|c|}
\hline \multicolumn{2}{|c|}{ Variable Codes and Name } & Measurement Unit & $\operatorname{Sign}(+/-)$ \\
\hline \multicolumn{4}{|c|}{ Dependant Variable } \\
\hline MSE_GR & Growth status & I if enterprise growing, 0 otherwise & \\
\hline \multicolumn{4}{|c|}{ Explanatory Variables } \\
\hline Entr_Comp & $\begin{array}{l}\text { Entrepreneurial } \\
\text { Competency }\end{array}$ & $\begin{array}{l}\mathrm{I}=\text { Very Low, } 2=\text { Low, } 3=\text { Medium } 4=\text { High and } 5=\text { Very High } \\
\text { Competency and transformed to mean values }\end{array}$ & + \\
\hline Mgt_Skill & Managerial Skills & $\begin{array}{l}\text { I=Very Low, } 2=\text { Low, } 3=\text { Medium, } 4=\text { High and } 5=\text { Very High } \\
\text { Skills \& transformed to mean values }\end{array}$ & + \\
\hline Mkt_Access & Access to Market & $\begin{array}{l}\mathrm{I}=\text { Very Low, } 2=\text { Low } 3=\text { Medium } 4=\text { High and } 5=\text { Very High } \\
\text { Access } \& \text { transformed to mean values }\end{array}$ & $0 /+$ \\
\hline Innov & Innovation & I if the enterprise introduce innovation, 0 otherwise & + \\
\hline
\end{tabular}




\begin{tabular}{|c|c|c|c|}
\hline Ini_Inv & $\begin{array}{l}\text { Initial } \\
\text { Investment Size }\end{array}$ & ETB (Ethiopian Birr) & + \\
\hline Fin_Access & Access to Finance & I if the enterprise has access to finance, 0 otherwise & + \\
\hline $\mathrm{Sec}$ & Enterprise Sectors & $\begin{array}{l}\mathrm{O}=\text { Manufacturing (Ref.), } \\
\mathrm{I}=\text { Construction, } \\
2=\text { Trade and } \\
3=\text { Service }\end{array}$ & + \\
\hline
\end{tabular}

\section{Results and Discussions}

\section{Descriptive Result and Discussions}

The descriptive statistics was run to observe the distribution of the factors or and variables. Of the total sample respondents interviewed, I 40 were non-growing and I03 were growing. Enterprise growth status was accounts $57.6 \%$ non-growing and 42.4 $\%$ growing of the total sample, respectively.

\section{Demographic characteristics of MSEs Owner/Manager}

As it is shown in table 4.1 below, $78.57 \%$ of non-growing respondents was male whereas, the corresponding figure for female respondent was 2I.43 percent. Male respondents comprise 76.7 percent of growing and the remaining 23.3 percent were female. Moreover, the chi-square test revealed that there is no a systematic association between enterprise growth and enterprises run by men and female respondent at I0 percent probability level. The findings showed that both men and women have the ability to run business, and experience at the same growth level.

Likewise, table 4.I below depicts distribution of the total sampled respondents by age is shown in table below indicates that $<20,20-30,3 \mathrm{I}-40$ and 4I-50 respondents accounted within for about 0.7I, 57.86, 36.43 and 5 percent for non-growing enterprise, and 2.9I, 59.22, 34.95 and 2.9I percent for growing, respectively. This shows that most of the sampled household heads in the study area were age between $20-30$ which accounts $58.44 \%$, and followed by $3 \mathrm{I}-40$ (35.8\%). The chisquare test revealed that there is no a systematic association between enterprise growth and age of respondents.

Table 4.I: Distribution of sample respondents by Gender and Age

\begin{tabular}{|c|c|c|c|c|c|c|c|c|c|}
\hline & & \multicolumn{2}{|c|}{ Non Growing } & \multirow{2}{*}{$\begin{array}{c}\text { Growing } \\
\text { Freq. }\end{array}$} & \multicolumn{3}{|c|}{ Total } & \multirow{2}{*}{$\chi^{2}$} & \multirow{2}{*}{$\begin{array}{c}\text { P- } \\
\text { value }\end{array}$} \\
\hline & & Freq. & Percent & & Percent & Freq. & Percent & & \\
\hline \multirow{3}{*}{ Gender } & Male & IIO & 78.57 & 79 & 76.7 & 189 & 77.78 & \multirow{3}{*}{0.1204} & \multirow{3}{*}{$0.729^{\text {tx }}$} \\
\hline & Female & 30 & 21.43 & 24 & 23.3 & 54 & 22.22 & & \\
\hline & Total & $\mathrm{I} 40$ & 100 & 103 & 100 & 243 & 100 & & \\
\hline \multirow{5}{*}{$\begin{array}{l}\text { Age } \\
\text { Respond } \\
\text { ents }\end{array}$} & $<20$ & I & $0.7 \mathrm{I}$ & 3 & $2.9 \mathrm{I}$ & 4 & 1.65 & \multirow{5}{*}{2.4256} & \multirow{5}{*}{$0.489^{\text {奖 }}$} \\
\hline & $20-30$ & $8 \mathrm{I}$ & 57.86 & $6 \mathrm{I}$ & 59.22 & $\mathrm{I} 42$ & 58.44 & & \\
\hline & $3 \mathrm{I}-40$ & $5 \mathrm{I}$ & 36.43 & 36 & 34.95 & 87 & 35.8 & & \\
\hline & $4 \mathrm{I}-50$ & 7 & 5 & 3 & $2.9 \mathrm{I}$ & $\mathrm{IO}$ & $4 . \mathrm{II}$ & & \\
\hline & Total & $\mathrm{I} 40$ & 100 & I03 & 100 & 243 & 100 & & \\
\hline
\end{tabular}

* is not significant at I0\% probability level

Source: Computed from survey of MSEs in West Shoa Zone

\section{Start up and Current number of employees of MSEs}

Table number 4.2 showed that number of employees' enterprise has been at start up and currently (number of employees at data collection time). MSEs which were hired less than 5 employees at start up stage constitute 209 (86\%). From these MSEs, II8 $(49 \%)$ and $9 \mathrm{I}(37 \%)$ were non-growing and growing enterprises, respectively. The chi-square test revealed that there is a systematic association between enterprise growth and number of employees at start up at less than $5 \%$ probability level. Likewise, MSEs which hired currently less than 5 employees constitute 193(79.4\%). From these MSEs, I22 (50.2\%) and $7 \mathrm{I}(29.2 \%)$ were non-growing and growing enterprises, respectively. The chi-square test revealed that there is a systematic association between enterprise growth and number of employees currently at less than $1 \%$ probability level. 
Table 4.2: MSEs Number of employees by

\begin{tabular}{|c|c|c|c|c|c|c|c|c|c|}
\hline \multirow{2}{*}{$\begin{array}{ll}\text { Size } & \text { of } \\
\text { Employees }\end{array}$} & \multirow[b]{2}{*}{ 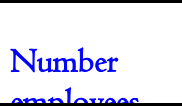 } & \multicolumn{2}{|c|}{ Non Growing } & \multirow{2}{*}{$\begin{array}{c}\text { Growing } \\
\text { Freq. }\end{array}$} & \multicolumn{3}{|c|}{ Total } & \multirow{2}{*}{$\chi^{2}$} & \multirow{2}{*}{$\begin{array}{c}\mathrm{P}- \\
\text { value }\end{array}$} \\
\hline & & Freq. & $\%$ & & $\%$ & Freq. & $\%$ & & \\
\hline \multirow{5}{*}{$\stackrel{\text { at }}{\text { Beginning }}$} & $\leq 5$ & II8 & 49 & $9 \mathrm{I}$ & 37 & 209 & 86 & \multirow{5}{*}{26.258} & \multirow{5}{*}{$.006^{*}$} \\
\hline & $\geq 6-10$ & II & 4.5 & 4 & 2 & I5 & 6 & & \\
\hline & $\geq$ II-I5 & I0 & $4 . \mathrm{I}$ & 6 & 2.5 & 16 & 7 & & \\
\hline & $>$ I5 & $\mathrm{I}$ & 0.4 & 2 & 0.5 & 3 & I & & \\
\hline & Total & 140 & 58 & I03 & 42 & 243 & 100 & & \\
\hline \multirow{5}{*}{ Currently } & $\leq 5$ & 122 & 50.2 & $7 \mathrm{I}$ & 29.2 & 193 & 79.4 & \multirow{5}{*}{ I09.862 } & \multirow{5}{*}{$.000^{* *}$} \\
\hline & $\geq 6-10$ & 10 & $4 . \mathrm{I}$ & 20 & 8.2 & 30 & I2.3 & & \\
\hline & $\geq$ II-I5 & 6 & 2.5 & 6 & 2.5 & 12 & 5 & & \\
\hline & $>\mathrm{I5}$ & 2 & 0.8 & 6 & 2.5 & 8 & 3.3 & & \\
\hline & Total & 140 & 57.6 & 103 & 42.4 & 243 & 100 & & \\
\hline
\end{tabular}

* is significant at I\% probability level

Source: Computed from survey of MSEs in West Shoa Zone, 2016

Descriptive analysis of factors that influence MSEs Growth

Table 4.3 below shows that the mean initial investment of the total sample respondent was found to be 6,54I.8 ETB with standard deviation of 7,729.4 ETB. The mean initial investment for non-growing was 3226.4 ETB and that of growing enterprises was 9857.2 ETB. The t-test revealed that the mean initial investment was significantly different at I\% probability level between non-growing and growing enterprises. This implied that as the initial investment increases, the probability of MSEs to register growth increases.

Table 4.3: Distribution of sample respondents by Initial Investment

\begin{tabular}{|c|c|c|c|c|c|c|c|c|}
\hline \multirow[t]{2}{*}{ Variables } & \multicolumn{2}{|c|}{ Non Growing } & \multicolumn{2}{|c|}{ Growing } & \multicolumn{2}{|c|}{ Total } & \multirow{2}{*}{$\begin{array}{c}\mathrm{t}- \\
\text { value }\end{array}$} & \multirow{2}{*}{$\begin{array}{c}\text { P- } \\
\text { value }\end{array}$} \\
\hline & Mean & $\mathrm{SD}$ & Mean & SD & Mean & SD & & \\
\hline Initial Investment & $3,226.4$ & $2,752.9$ & $9,857.2$ & $12,705.9$ & $6,541.8$ & $7,729.4$ & -5.99 & $.000^{24}$ \\
\hline
\end{tabular}

* is significant at less than I\% probability level.

$$
S D=\text { standard deviation }
$$

Source: Computed from survey of MSEs in West Shoa Zone

As it is shown in table 4.4 below, out of 243 sampled respondents $37.45 \%$ was only engaged in innovation and $37.04 \%$ had access to finance. The result further indicates that $89.28 \%$ of non-growing enterprises was not engaged in innovation whereas; the corresponding figure for innovated enterprises was $10.7 \mathrm{I} \%$. On the other hand, $73.79 \%$ of innovated enterprises were growing and the remaining 26.2I percent of growing MSEs were not engaged in innovation. Likewise, the chisquare test showed that there was a systematic association between enterprise growth and participation in innovation activity at I percent probability level.

The result further indicated that $78.57 \%$ of non- growing respondents had not been accessed to finance whereas, the corresponding figure that had access to finance were $21.43 \%$. The growing MSEs of $58.25 \%$ had access to finance and the remaining 4I.75 percent had not access to finance. Similarly, the chi-square value (34.506) showed that there was a systematic association between enterprise growth status and access to finance at I percent probability level.

Table 4.4: Sample respondents by engagement in innovation activity and Access to Finance

\begin{tabular}{|c|c|c|c|c|c|c|c|c|c|}
\hline \multirow[t]{2}{*}{ Enterprises } & & \multicolumn{2}{|c|}{ Non Growing } & \multirow{2}{*}{$\begin{array}{c}\text { Growing } \\
\text { Freq. }\end{array}$} & \multicolumn{3}{|c|}{ Total } & \multirow{2}{*}{$x^{2}$} & \multirow[t]{2}{*}{ P- } \\
\hline & & Freq. & $\%$ & & $\%$ & Freq. & $\%$ & & \\
\hline \multirow[b]{2}{*}{ Innovation } & Yes & 15 & I0.7I & 76 & 73.79 & $9 \mathrm{I}$ & 37.45 & 100.777 & $.000^{* 4}$ \\
\hline & $\mathrm{No}$ & 125 & 89.28 & 27 & 26.21 & I52 & 62.55 & & \\
\hline
\end{tabular}




\begin{tabular}{|c|c|c|c|c|c|c|c|c|c|c|}
\hline & & Total & $I 40$ & 100 & $I 03$ & 100 & 243 & 100 & & \\
\hline \multirow{3}{*}{$\begin{array}{l}\text { Access } \\
\text { Finance }\end{array}$} & \multirow{3}{*}{ to } & Yes & 30 & 21.43 & 60 & 58.25 & 90 & 37.04 & \multirow[t]{3}{*}{34.506} & \multirow[t]{3}{*}{$.000^{*}$} \\
\hline & & No & IIO & 78.57 & 43 & $4 \mathrm{I} .75$ & I53 & 62.96 & & \\
\hline & & Total & $I 40$ & 100 & 103 & 100 & 243 & 100 & & \\
\hline
\end{tabular}

* is significant at less than $1 \%$ probability level

Source: Computed from survey of MSEs in West Shoa Zone

Table 4.5 below showed distribution of sample respondent by sector of enterprise. The result indicate that Manufacturing, Construction, Trade and Service respondent accounted for about I2.I4, 9.28, 42.86 and 35.7I percent for non growing enterprise, and 62.I4, 6.8, I6.5 and I4.56 percent for growing, respectively. The result showed that those in manufacturing sector has been registered higher growth than other sectors like construction, trade and service. Moreover, the chi-square test (67.87I) showed that there was statistically significant difference between enterprise sector and MSEs growth at less than I\% probability level.

Table 4.5: Distribution of sample respondents by Sector

\begin{tabular}{|c|c|c|c|c|c|c|c|c|}
\hline \multirow[b]{2}{*}{ Sector } & \multicolumn{2}{|c|}{ Non Growing } & \multicolumn{2}{|c|}{ Growing } & \multicolumn{2}{|c|}{ Total } & \multirow{2}{*}{$\chi^{2}$} & \multirow{2}{*}{$\begin{array}{c}\text { P- } \\
\text { value }\end{array}$} \\
\hline & Freq. & Percent & Freq. & Percent & Freq. & Percent & & \\
\hline Manufacturing & I7 & $\mathrm{I} 2 . \mathrm{I} 4$ & 64 & 62.14 & $8 \mathrm{I}$ & 33.33 & \multirow{5}{*}{$67.87 \mathrm{I}$} & \multirow{5}{*}{$.000^{\text {*x }}$} \\
\hline Construction & I3 & 9.28 & 7 & 6.8 & 20 & 8.23 & & \\
\hline Trade & 60 & 42.86 & I7 & I6.5 & 77 & 31.69 & & \\
\hline Service & 50 & $35.7 \mathrm{I}$ & I5 & I4.56 & 65 & 26.75 & & \\
\hline Total & $\mathrm{I} 40$ & 100 & I03 & 100 & 243 & 100 & & \\
\hline
\end{tabular}

is significant at less than $1 \%$ probability level.

Source: Computed from survey of MSEs in West Shoa Zone

MSEs owner/manager response related to entrepreneurship competency, management skill and market access of enterprises were depicted on the table 4.6 below using mean and SD. The MSEs entrepreneurship competency was measured using five scale in which Very low Competency (VLC=I), Low Competency ( $\mathrm{LC}=2$ ), Medium Competency (MC=3), High Competency $(\mathrm{HC}=4)$ and Very High Competency $(\mathrm{VHC}=5)$. Based on this measurement, comparatively the growing MSEs mean was greater than that of non-growing (I.7398 > I.3200). The output also indicated the two groups of the MSEs (Growing \& Non-growing) are positive and significance at less than I\% level of significance. Therefore, it can be concluded that entrepreneurship competency is among the main factor that influence the growth of MSEs.

Similarly, management skill which is measured using five scale Very Low skill =I, Low skill =2, Medium Skill =3, High Skill $=4$ and Very High Skill=5); and market access which is measured (using five scale i.e. Very Low access =I, Low access $=2$, Medium access $=3$, High access $=4$ and Very high access $=5$ were depicted in the table 4.6 below. The result of both variables showed that the mean score of the two groups of the MSEs (Growing \& Non-growing) are positive and significance at less than I\% level of significance. Therefore, it can be concluded that very low management skill and Market access are among main factor that negatively affects the growth of MSEs in the West Shoa Zone of selected towns.

Table 4.6: MSEs Growth Status in relation to Competency, Skill and Market access

\begin{tabular}{|c|c|c|c|c|c|c|c|}
\hline Variables & $\begin{array}{c}\text { MSEs } \\
\text { Growth status }\end{array}$ & $\begin{array}{c}\mathrm{n}= \\
(243)\end{array}$ & Mean & $\begin{array}{l}\text { Std. } \\
\text { Dev. }\end{array}$ & $\begin{array}{l}\text { Std. } \\
\text { Error }\end{array}$ & $\mathrm{F}$ & Sig. \\
\hline \multirow{2}{*}{$\begin{array}{l}\text { Entrepreneurship } \\
\text { Competency }\end{array}$} & Non-growing & 140 & 1.3200 & .35849 & .03030 & \multirow[b]{2}{*}{$\begin{array}{c}\mathrm{IOI} .42 \\
2\end{array}$} & \multirow[b]{2}{*}{$.000^{4}$} \\
\hline & Growing & 103 & 1.7398 & .26172 & .02579 & & \\
\hline \multirow[t]{2}{*}{ Management Skill } & Non-growing & $\mathrm{I} 40$ & 1.4920 & .32410 & .02739 & \multirow{2}{*}{61.274} & \multirow{2}{*}{$.000^{*}$} \\
\hline & Growing & I03 & 1.7888 & .24192 & .02384 & & \\
\hline Market Access & Non-growing & $\mathrm{I} 40$ & I.I524 & .41768 & .03530 & & \\
\hline
\end{tabular}




\begin{tabular}{|c|c|c|c|c|c|}
\hline Growing & $\begin{array}{ll}\mathrm{I} 03 & \mathrm{I} .62 \mathrm{I} 4\end{array}$ & .28315 & .02790 & 97.002 & $.000^{* *}$ \\
\hline
\end{tabular}

\section{Logistic Regression Results and Discussions}

As it is discussed earlier in the descriptive analysis, the statistics results revealed that non -growing and growing enterprises respondent groups have statistically significant difference with respect to mean of the continuous variables (such as Initial Investment size, Entrepreneurship Competency, Management Skill and Market Access) and Categorical variables (Access to Finance, Innovation, Sector, number of employees). In order to identify the factors which determine growth of enterprise most in the study area from the hypothesized variables, binary logit model was estimated by employing STATA Version I2.0 statistical package.

\section{Evaluation of Assumptions}

Before doing the description of the logistic regression results, the assumptions held in the logistic model under investigation treated first and then followed by analysis of model results and discussions. Therefore, multi-co linearity, heteroskedasity and model fitness were used to check the assumptions below for this study.

In order to test the existence of multi-co linearity problem, VIF (Variance Inflation Factor) is utilized. Multi-co linearity- tests whether there are perfect linear relationships among the explanatory variables or not (Gujarati, 2004). As a rule of thumb for multi-co linearity test, the VIF and I/VIF of the study shouldn't greater than IO and less than 0.I, respectively. Thus, in this study there is no multi-co linearity problem existed among explanatory variables.

Test of heteroskedasticity shows the null hypothesis that the variance of the residuals is homogeneous. If $\mathrm{p}$ value is very small, i.e., $\operatorname{Pr}<0.05$ (at 95\% confidence), the null hypothesis would be rejected and accept the alternative hypothesis that the variance is not homogenous (Gujarati, 2004). MSEs Growth equation is estimated by using logistic model estimation shows there is no problem of heteroskedasticity. The null hypothesis (i.e., Ho: Constant variance) was rejected because the test result showed. Prob $>\mathrm{chi}^{2}=0.4707$, which is greater than the significance level ( 10 percent). Therefore, the result indicated that there is equal variance among the error terms. Therefore, there was no problem of heteroskedasticity in the process of model specification.

\section{Logistic Regression and Results}

The variables described below were used to estimate the logistic regression model by using the maximum likelihood estimation procedure. As indicated in tables 4.7 below, entrepreneurship competency, management skill, market access, initial investment size and enterprises in manufacturing sector were positively influenced the probability of MSEs growth whereas, innovation and access to finance are negatively influenced the growth probability of MSEs. All these variables are found in line with our priori expectation except for Innovation and Access to Finance variables. The results of the logistic regression analysis on the determinants of MSEs growth were reported in table 4.7 bellow. Results have shown that the variables included in the model explain about $73.38 \%$ of the influences on the MSEs growth.

Table 4.7: Logistic Model result of determinants of MSEs growth

$$
\begin{array}{ll}
\text { LR chi2 }(9)= & 243.03 \\
\text { Prob }>\text { chi2 }= & 0.0000 \\
\text { Pseudo R2 }= & 0.7338
\end{array}
$$

Log likelihood $=-44.090388$

Dependent Variable : MSEs Growth Status (MSE-GR)

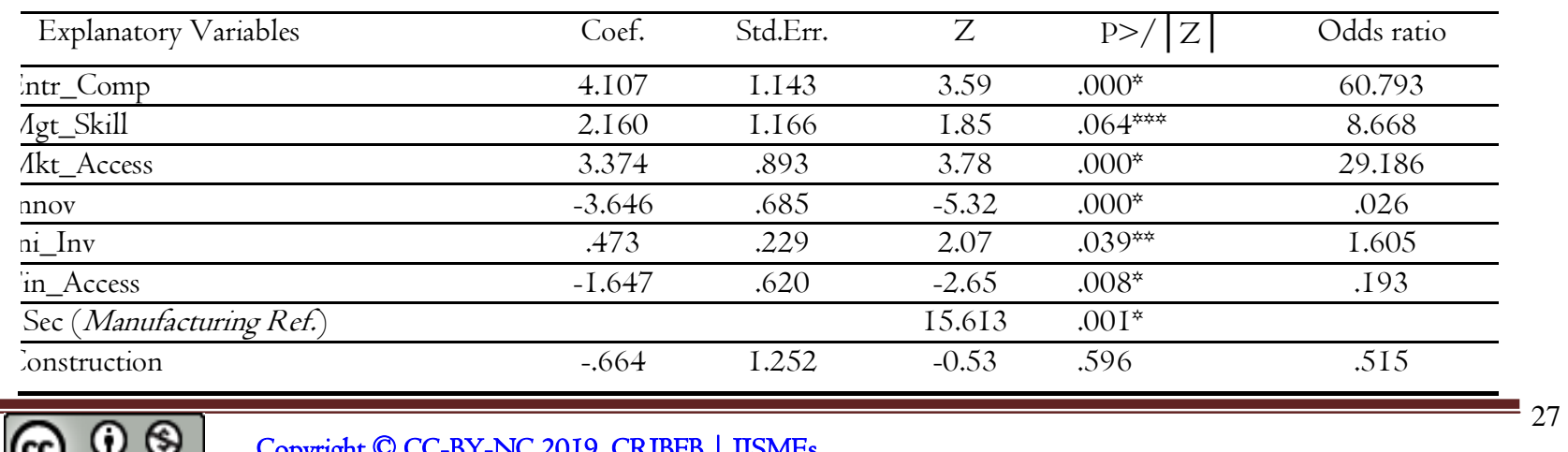




\begin{tabular}{|c|c|c|c|c|c|}
\hline rade & -2.553 & $.7 \mathrm{I} 4$ & -3.57 & $.000^{2 x}$ & .078 \\
\hline ervice & -2.364 & .756 & -3.13 & $.002^{x}$ & .094 \\
\hline jons_ & -8.853 & 3.838 & 5.322 & 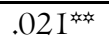 & .000 \\
\hline
\end{tabular}

* is significant, is significant, is significant at less than $I, 5,10 \%$, respectively

Source: Computed from survey of MSEs in West Shoa Zone

Binary logistic regression model was used to examine the impact of the independent variables on the dependent variable (growth status of MSEs). Besides, though the logit and the probit model yield similar parameter estimates, the logit model is preferred because of its comparative mathematical simplicity and more meaningful interpretation of odds ratio (Gujarati, 2004). The more crucial to the interpretation of logistic regression is the value of the odds ratio which is an indicator of the change in odds resulting from a unit change in the predictor. The logistic regression equation expresses the multiple linear regression equation in logarithmic terms (called the logit) and thus overcomes the problem of violating the assumption of linearity.

From the output of logistic regression model shown in the table 10 above, the value of odds ratio (Exp B) and P-value for entrepreneurship competency was 60.79 and 0.000 , respectively. This shows that entrepreneurship competency has significant impact on the growth of MSEs. Hence, this research attested the hypothesis that says "relatively the better entrepreneurship competency of the MSEs, the higher the chance of the MSEs growth". The odds ratio of this variable explains the probability of growing for those MSEs having entrepreneurship competency which is 60.79 times higher than the MSEs that has no entrepreneurship competency. This result is more consistent with the previous study of Kamau and Ngugi (20I4) which infer that entrepreneur skill has a significant and positive effect on growth of the firm.

From the above table 10, the odds ratio and P-value for management skill were 8.67 and 0.064 , respectively. This result shows that the probability of growing for MSEs that have management skill was 8.67 times higher than the MSEs that have not these skills. This variable had a positive sign and shows statistically significant at $10 \%$ of level of significance. Then, the res earch proved the hypothesis that states "relatively the better managerial skills of the MSEs, the higher the chance of the MSEs Growth". This result is more consistent with the previous study of Ongoroet al., (2013) that depicted managerial skills have a positive and significant influence on the growth of MSEs.

The results indicated a positive relationship between MSEs Growth and market access. As a result, the odds indicates that the growth of MSEs that did not have access to market is 29.19 times lower than those which have good marketing access and also has statistical significant at I percent level of significance. Thus, the researchers accepted the hypothesis which states "MSEs that have better market access have the higher probability of growth as compared to those MSEs that have poor market access". This result finding is similar with the previous study of Ishengoma and Kappel (20I I) that indicates access to markets has a significant and positive effect on the MSEs in manufacturing enterprises in Uganda.

The study revealed the relationship of innovation and MSEs Growth were inversely related which implies innovation has negative impact on the growth of MSEs and has significant effect at I percent level of significance. In this case, the MSEs that have participated in the innovation their growth was lower by 0.026 than those that have not participated in the innovation (i.e. as innovation increase by one unit the growth of MSEs was decreased by 0.026 units). As a result, the hypothesis which stated "MSEs that are engaged in innovation activity likely grow faster than the non-innovators MSEs" was rejected. This study contradicts the previous study done by Mulu (2009) which concludes that MSEs innovators grow faster than non-innovators. This result may be quite true in case of MSEs growth in short run which might be affected by low market share due to less customers need assessment for innovation, low sale volume (low profit) and high initial cost which cannot contribute for the MSEs growth in the short run. This might be due to less customer need identification for innovation which result, low market share and low sale volume (low profit); and high initial cost which do not contribute for the MSEs growth in the short run. MSEs in unstable condition cannot also increase their chances of probability of growth in being more innovative than their counterpart even if they are wasting a large amount of resources. Then, in this condition, even if MSEs that participate in the innovation, their growth may be low compared to those MSEs do not participate in the innovation activities. This might be different in long term, engaging in innovation activity can contribute a lot for the growth of MSEs in the study areas.

Initial investment size has a positive effect on the growth of MSEs. The odds ratio of this variable is I.6I which implies that the probability of growing of MSEs which have the higher initial investment sizes increased by I.6I times than that of which MSEs started with low initial investment size. This factor shows that statistical significant at the 0.039 p-value which is failed to reject the hypothesis that states "relatively the higher the initial investment sizes of the MSEs, the higher the chance of the MSEs growth". Therefore, as the initial investment size of MSEs is high, the probability of MSEs growth is also high. The previous study of Habtamu et al (2013) indicated that the initial investment has a lot of contribution for the growth of 
MSEs. Moreover, in this study, as the initial investment increase, there is a trend of MSEs shifting from least growing sector such as trading to higher growing sectors such as manufacturing.

The results of this study showed a negative relationship between access to finance and MSEs growth at 5 percent significance level. A unit increase in access to finance by one, MSEs' growth probability reduced compared to non-access to finance by 0.19 units. As a result, the hypothesis which states "MSEs that have better access to finance, the higher probability of growth as compared to those MSEs that have poor access to finance" was rejected. In spite of getting access to finance, MSEs in developing countries are used for different purposes rather than used to invest directly to business for example expending for the consumption, and covering different personal costs; and some other factors within the firm such as managerial incompetence might explain poor understanding on how to utilize finance. Therefore, access to finance can harm firm growth by increasing debt and this might in turn lead to the MSEs high debt, unable to pay loan interest and results low growth of MSEs even to the collapse of the enterprise. This study result contradicts with the result of Siyoum (2012) and Eshetu and Zeleke (2008) which stated that access to credit from formal financial sources has significant positive effect on MSEs growth. The implication of these results is that operators of MSEs that grew slow could avoid costs of spending capital in different ways other than business areas.

Assuming all other factors remains constant; the chance of growth for MSEs that engaged in the construction sector may decrease by $0.5 \mathrm{I}$ compared to MSEs that operate in manufacturing sector. Similarly, the likelihood of growth for MSEs that participate in trade sector was decreases by 0.08 than manufacturing sector. In addition, the odds of growth for MSEs that engaged in service sector decreases by 0.09 compared to MSEs that operates in manufacturing sector. Therefore, the hypothesis in this case "MSEs that are engaged in manufacturing sector have higher chance of growth than others" was accepted except for those MSEs that are engaging in construction sector. This study result is consistent with the study of Habtamuet al., (2013) and Gebreyesus (2007) that depicts MSEs operating in manufacturing sector grow faster than those operate in other sectors.

\section{Conclusion and Recommendation \\ Conclusion}

This study was aimed to analyze the determinants of MSEs growth of West Shoa Zone, Oromia, region Ethiopia, based on the sample of 243 enterprise owner/manager drawn from three towns, Ambo, Gedo and Bako. Both descriptive analysis and logistics regression estimation results were used to answer the intended objectives. Therefore, based on the findings, following conclusions are forwarded.

MSEs have an important contributor to economic growth and employment creation in Ethiopia. This contribution is determined by different restraining factors. Due to different bottlenecks that hinder the growth, MSEs which are found the three towns were not grown as it was expected. Non-growing and growing enterprises respondent groups have statistically significant difference with respect to the number of employees at start up and currently. MSEs Owner/manager characteristics such as gender and age were found not to have influences on the growth probability of the enterprises.

The model result reveals that entrepreneurship competency, management skill, and market access have positive and significant impact on the probability of MSEs growth in study area. Hence, MSEs that were relatively lower entrepreneurship competency, management skill and market access have lower probability of growth compared to those MSEs that were better in competency, skill and access to the market.

Getting access to finance and engaging in innovation activity have negative impact on the growth probability of MSEs in the study. This can be explained by the fact that those MSEs that have been accessing loan service were lower growth rate probability relatively to those MSEs had not get access to finance. Initial investment size and sector variable have positive impact and statistically significant on MSEs growth. MSEs that were started with higher initial investment size have the probability of growing compared to MSEs that were started with lower initial investment. MSEs operate in manufacturing and construction sector have high growth probability relatively than MSEs in other sectors (Trade and Service). This might be due to high need in the side of consumer, and government gives more attention for manufacturing and construction sector thereby promote infrastructure in the country.

\section{Recommendation}

This study might have recommendations on the determinants of MSEs growth in West Shoa Zone, Oromia Region, Ethiopia. The role of MSEs in this area was consistently recognized in high employment and income generating and has become a major playing field for policy makers and donors with dual objective of enhancing growth and alleviating poverty. Entrepreneurial competency, managerial skills, market access, innovation, high initial investment, access to finance and being manufacturing sector were identified as major determinants of growth of the MSEs in the study area. Then, proper understanding of these factors constitutes an essential starting point and important for the governmental and non-governmental organizations to formulate policies and strategies in order to reduce poverty, unemployment and income inequality. Based on the findings of the 
study, the following recommendations were forwarded to MSEs owner/manager, government and MSEs agency office, and NGOs to promote MSEs and their performance in the study area.

\section{For Owner/Manager of MSEs}

Due to low implementation of growth strategies, the probability of MSEs growth was low. Therefore, owner/manager of MSEs should upgrade entrepreneurial competence through effective implementation of growth strategies such as appropriate utilization of factors of production (effective controlling of human resources and capital), effective selection of business partners, proper training for employees, and sharing experience from other MSEs that are better in growth.

To have sustainable growth, MSEs owner/manager should equipped him/her with management skills such as; setting a goal based on systematic planning, seeking opportunity persistently, maintaining efficiency and quality in to consideration by taking business risk and developing good business network.

MSEs should make themselves clear with the current and future need of customers for innovated products/service before engaging in any innovative activity. In the process of innovation development, MSEs should follow least cost strategy and use byproduct as input materials so that they can make the product available at fair price for customers and avoid shortage of markets for innovative products currently facing. However, in long terms, MSEs that are engaged in innovation activity may contribute positively for their growth, therefore, for MSEs it is advisable to continue doing innovation activities in a very efficient manner.

\section{For Government and MSEs Agency Office}

The MSEs development office of the selected towns should promote MSEs growth through getting access to exhibition and tradeshows, making enterprises to have access to updated market information, creating market linkage for MSEs to participate equally without any favoritism in government procurement thereby improve MSEs access to market. Moreover, sufficient managerial skill and market access development training should be provided for MSE operators to change the traditional way of operating, and marketing business should have modern types of production and marketing.

The government should support MSEs to show progressive development in their growth through consulting them and to adopt lower cost strategy, and to do their operation in a more effective way. Getting these encouragements is a vital for MSEs to utilize their resources in effective ways. The quality, distance from main road, and accessibility of infrastructures should be considered in the provision of working space to the enterprises.

Other concerned bodies like universities should invite MSEs to enable them to be participated in seminars and workshops to improve MSEs' capabilities, skills and access to information and to increase their profitability which can serve as the best resource acquisition strategy for new ventures in selected towns in Ethiopia.

MSEs and Ambo town administration office should undertake detailed study on the suitability of business environment, identifying business areas where MSEs can successfully participate such as supplier, intermediaries, and developing mechanisms whereby product quality and unit costs are improved. As a result integrating MSEs are important in those identified business activities without disturbing the market mechanism and merit system. Moreover, it is better if the MSEs' agency office advise the new enterprises to engage in manufacturing and construction sectors than other sectors like trade and service.

\section{For Development Practitioners (NGO's)}

NGOs should provide capacity building training for MSEs on efficient utilization of finance specifically to finance management, proper utilization of loan, loan repayment, revenue generation and reinvestment of returns thereby MSEs growth couldn't be obstacle due to increase debt of loan interest. In collaboration with other concerned body, NGOs can support the growth of MSEs through providing consultancy service, facilitating market access for innovated products and encouraging MSEs innovation through introducing least cost method of production.

\section{Limitations of the Study}

This study, like any other studies, has a number of limitations, though its impact did not limit the validity of the study. One of the critical limitations in this regard was the unwillingness of the surveyed MSEs to provide information. It was found that MSEs operators were largely reluctant to give their time to respond to the survey questionnaires for various reasons. So, repeated visits and attempts of clarifying objective of the visit were tiresome and time taking. It was also observed from the interview that there seems to be memory laps on the part of the respondents to respond on some issues related to quantitative variables (rely on a recall to measure the number of employees) since there was no recording practice in most of the sample enterprises. 


\section{Acknowledgements}

The successful completion of this study was done with the support of Almighty God to whom we owe a great gratitude, as we shall continue to remain thankful to Him. Special thanks goes to West Shoa Zone Micro and Small Enterprises Bureau staff and particularly, Ambo, Gedo and Bako town woredas office for their cooperation and kindness in providing access to information. Finally, we remain indebted to Ambo University for funding this research and our friends for their kind support and constructive comments especially Henos Ejigu on language edition during writing up of the paper.

\section{References}

Baldwin, (1995) the Determinants of Small Firm Growth, an Inter-regional Study in the U.K., Sassica Kingsley, England.

Barney, J. (I99I) 'Firm resources and sustained competitive advantage.' Journal of Management, I7, pp. 99-I 20.

Central Statistical Authority (CSA) (2004) Report on Small Scale manufacturing. Industries Survey, Addis Ababa.

Central Statistical Authority (CSA) (2007) Report on Small Scale manufacturing. Industries Survey, Addis Ababa.

Cheng, R.W. (2006). Determinants of growth in small and medium enterprise: An empirical study on logistic industry in Hongkong. Unplished $\mathrm{PhD}$ thesis, Curtin University of Technology. Australia.

Egbuogu, L.O.D. (2003) What Small Business Entrepreneurs Expect From Local Credit Agencies and International Business Facilitators". Paper presented at "Business America". A Forum organized by the US Commercial Consulate, Lagos, Nigeria, March 3, pp. I-IO.enterprises. South African Journal of Economics, 76 (3).

Eshetu, B., \& Zeleke, W. (2008). Factors that affect the long term survival of micro, small and medium

Fabayo, J.A. (2009) Small and Medium Enterprises development strategy: A critical Option for sustainable Long -Term Economic Development in Nigeria. A paper presented at the first Annual International Conference on: Ijebu -Ode held from 25 - 27 August.

Gebreeyesus, M. (2007). Growth of Micro-Enterprises: Empirical evidence from Ethiopia

Gujarati, (2004). Basic Econometrics 3rd edition

Habtamu T. Aregawi G. and Nigus A. (2013), Growth Determinants of Micro and Small Enterprises: Evidence from Northern Ethiopia: Journal of Economics and Sustainable Development, Vol.4, No. 9, PP. I27-I34

ILO.2005. "Creating a Conducive Policy Environment for Micro, Small and Medium Sized Enterprisesin Pakistan.” SEED Working Paper No.29.

Ishengoma, E. Kappel, R. (20I I): Linkages as Determinants of Industrial Dynamics and Pov-rty Alleviation in Developing Countries, in: Dey, D. (ed.): Informal Sector in a Globalized Era, Hyderabad, 89-199.

Kamau, J. M. \&Ngugi, J. K. (20I4). Factors affecting the growth of small and micro enterprises dairy farmers' in Kenya: Case of Gatundu South Farmer's Dairy Co-operative Society Ltd. International Journal of Current Business and Social Sciences, I (I), 48-63.

Maad, D. C., \&Liedholm, C., (2008). The dynamics of micro \& small enterprises in developing countries. Journal of Finance, 26 (I),

Mano, Y., Iddrisu, A., Yoshino, Y., and Sonobe, T. (201I). How Can Micro and Small Enterprises in Sub-Saharan Africa Become More Productive? The Impacts of Experimental Basic Managerial Training. Tokyo: National Graduate Institute for Policy Studies.Mulhern,

Margi Levy and Philip Powell (2005): SME Internet Adoption: Towards a Transporter Model, Centre for Information Management, School of Management, University of Bath.

Marlow, S. and Carter, S. (2006) "If you don't ask you don't get! Women, self -employment and finance", paper presented to Warwick Business School Small Firms Finance Conference, May, Coventry

McCartan -Quinn, D. and Carson, D. (2003), 'Issues which impact upon marketing in the small firm', Small Business Economics, Vol.2I, No.2, pp.20I-2I3

MSEs west Shoa zone office Report, 2006 E.C

Mulu Gebreeyesus. (2009). Innovation and Microenterprises Growth in Ethiopia. Word Institute for Development, Economic research, United Nations University, No. 51.

Ongoro Z., Kiragu M. and Simwa S.(2013). Effect of managerial skills on growth of hotel based Micro and Small Enterprises in keroka, Kenya: interdisciplinary journal of contemporary research in business, 370, vol 4, no 12

Ruhiu, R. W., Ngugi, P. K. \&Waititu, G. A. (20I4).Effects of managerial skills on the growth of incubated micro and small enterprises in Kenya.International Journal of Social Sciences and Entrepreneurship, I (I2), 474-485.

Sengendo, H. Oyana, T. Nakileza, B. Musali, P. (200I): The Informal Sector in Employment Creation in Kampala, in: Alila, P.O.Pedersen, P.O. (eds.): Negotiating Social Space: East African Micro-Enterprises, Asmara.

Siyoum, G. (2012). Business constraints and growth potential of micro and small enterprises. Evidence from Holeta Town (Master Thesis) Mekelle University, Ethiopia. 
Solomon W. (2005), Socio Economic Determinants of Growth of Small Manufacturing Enterprises in Addis Ababa, Addis Ababa University, School of Graduate Studies.

Storey, D. J. Understanding the small business sector. International Thomson Business Press, London, I994, ISBN 9780415100380.

Tarmidi, L.T. (2005). The importance of SMEs in economic development of developing APEC countries. Paper presented at the APEC Study Center Consortium Conference. Jeju, Korea: 22-25 May

Wolfenson, J.D.(200I) Comparing the performance of male and Female -controlled businesses: relating output to inputs. Entreprenuership Theory and Practice.26 (3).pP 9I-I00.

\section{Copyrights}

Copyright for this article is retained by the author(s), with first publication rights granted to the journal. This is an open-access article distributed under the terms and conditions of the Creative Commons Attribution license (http://creativecommons.org/licenses/by/4.0/). 